\title{
Challenges to the Execution of the UN Mandate in Central African Republic
}

\author{
Elijah Mwasi Mwanyika \\ Kenya Defence Forces senior officer
}

Kenya

\begin{abstract}
United Nations (UN) Peace Keeping Operations (PKOs) are often faced with numerous challenges. These include lack of clarity in implementation procedures, environmental challenges including language as well as, different customs, and ideology existing within the mission groups among others. This study sought to examine the challenges to the execution of the UN Mandate with reference to the "UN Multidimensional Integrated Stabilization Mission in the Central African Republic", (MINUSCA). Data was obtained from books, e-books, journals, UN publications and websites. The collected data was analyzed thematically so as to establish the efficacy of UN intervention in light of the identified contemporary challenges. The findings show that the execution of the UN Mandate in the Central African Republic is implemented in a complex environment. The UN during its planning for PKOs may have not considered the national institutional capabilities in CAR that were expected to support MINUSCA in the execution of its Mandate. It can also be concluded that challenges to the MNUSCA mandate execution lie in the ability and capability of the rehatted troops from MISCA to MINUSCA which emanated from the inherent inability of the UN to raise enough troops for its PKOS. In this regard, the principles of peacekeeping; impartiality, consent and non-UoF except in self-defense as well as the defense of the mandate must be reviewed so as to be effective in contemporary PKOs.
\end{abstract}

Key Words: Central Africa Republic; MINUSCA; UN Peace Keeping Operations; Challenges Facing UN Mandates.

\section{INTRODUCTION}

Peace keeping interventions are riddled with various challenges that make it hard for peacekeepers to effectively fulfil their mandates. In some cases, this is attributable to capabilities that are not in conformity with mandated tasks or when Troop Contributing Countries (TCCs) lack political will. Other challenges emanate from lack of clarity in implementation procedures, environmental challenges including language as well as, different customs, and ideology existing within the mission groups [1]. For example in MONUSCO troops deployed in the same mission have different mandates.

UN interventions have faced challenges related to complex nature of the peacekeeping environment [2] which is some cases withdrawal of troops have been experienced. Withdrawal of such troops has been associated with policy change by TCCs where lives of its nationals have been lost due to attacks by the belligerents. US troops in Somalia [1] and Austrian troops deployed in the Golan Heights (UN Disengagement Observer Force) [3] withdrew from UN missions in 1994 and 2013 respectively following the killings of their nationals. When such incidents occur, the UNs ability to successfully execute its mandates is severely compromised due to its dependence on member states for troops/police contribution and logistic support [4]. This study sets out to examine the challenges to the execution of the UN Mandate in Central African Republic.

\subsection{Statement of the Problem}

Though a large number of UN interventions have been successful, they are often confronted by a myriad of challenges which include lack of capacity, poor implementation of the mandate, environmental issues, continued fighting leading to the inability to contain the violence and interference by the host Nation. While executing their mandate, misconduct by the intervening forces and civilian members of staff has undermined the legitimacy and credibility of such missions. In some of the missions today, despite the fact that the mandates are clearly defined, intervening forces especially UN peacekeepers have been criticized and blamed for inefficiency and misconduct leading to loss of civilian lives. However, it is untenable to understand the gravity of all the challenges facing specific peacekeeping operations (PKOs) in Africa such as the UN Multidimensional Integrated Stabilization Mission in the Central African Republic,"(MINUSCA) without targeted studies. This means that making 
responsive strategies for reining in on these challenges remains a hard feat. In this light, this current study sought to examine the challenges to the execution of the UN Mandate in Central African Republic.

\subsection{Research objective}

The study aimed at examining the challenges to the execution of the UN Mandate in Central African Republic.

\section{LITERATURE REVIEW}

\subsection{Challenges to the Execution of the UN Mandate}

Extant literature shows that peace support operations have increasingly become complicated due to an array of challenges. Currently, peacekeeping is faced with challenges related with, "mix of capabilities, procedure, equipment, language, customs, and ideology existing within the mission groups" [1]. This has led to a more complex peacekeeping environment, leading to an increase in the loss of life and equipment [2]. In some instances, loss of peacekeepers has been known to prompt demands for withdrawal, though not very common. One such example is the withdrawal of United States in 1993 from Somalia in the wake of the attack and killing of some of its troops in Mogadishu [1]. Another example is the withdrawal in 2013 from the Golan Heights of Austrian troops (UN Disengagement Observer Force) for safety reasons.

Contribution of troops or equipment to UNPKOs is not compulsory under the UN Charter [5] and therefore this continues to undermine most UNPKOs since the quality and quantity of troops deployed is dependent on the voluntary contribution by member states. In most instances, States vote in support of the deployment of PKMs, yet they fail to support such missions by contribution of troops or finances [6]. At times even when the forces deploy, they lack the capability to deal with the demands of the PKOs and often take orders from their capitals not the UN. This makes it untenable for PKMs to yield the intended fruits since instructions that are perceived to be in contravention of national policies of the deployed troops are hardly respected. This often undermines the success of UN PKMs as argued by this study. In most cases, member States especially developed countries; provide equipment and rarely contribute troops, while developing countries contribute troops.

Mobilization of troops and resources in a timely manner has always been a challenge to the UN [7]. For example, after the signing of a peace agreement in 2014 between SPLA and SPLA-IO in South Sudan, a request was made to increase the number of troops to UNMISS for purposes of helping in monitoring the implementation of the ceasefire; however none of the TCCs that were approached was ready to deploy these troops. Although the UN maintained the Standby Arrangement System (UNSAS) which was a "database which contained details of member states available to provide troops to the UN at short notice," speedy deployment of troops has yet to be effectively realized. Today, the UN has further developed the standby arrangements to become "the Peacekeeping Capability Readiness System (PCRS)." This is aimed "at putting in place a process that is predictable and dynamic so as to foster UNHQ-Member States interactions." In so doing, PCRS would contribute to "enhanced readiness and prompt deployment of responsive peacekeeping capabilities" [8]. To ensure predictability, standardization and efficiency, these guidelines establish clearly defined criteria and a set process for registration and verification to be followed by Member States and the UN Secretariat [8]. Though this is the case, timely availability of critical capabilities from member states is still a challenge.

Given that Chapter VIII of the UN charter espouses the interventions that regional organizations could undertake, the UN has from time to time encouraged such interventions. However, in most cases these troops do not have the requisite training and capability to effectively manage the conflicts. A case in point is the deployment of International Support Mission to the Central African Republic (MISCA) as well as the African Union Mission in Darfur (AMIS) in 2004. Although the MISCA troops could not contribute to stability or rein in on attacks on civilians, "it is notable that the peacekeepers were accused of undertaking coldblooded attacks whose evidence they promptly endeavoured to cover up" [9]. Failure to execute its mandate, the Mission was wound up and rehatted to a MINUSCA however; most of the same ill equipped forces were retained.

According to Dorussen, in a conflict environment, rebel groups are more likely, to contest the legitimacy of a UN mission while governments are less likely to [10]. However in some cases such as Sudan and South Sudan both parties contest peacekeeping to an extent of the government wanting to control the operation of the mission. Robert argues that success of third party intervention largely depends on the belligerents perceptions on the enforceability of the outcomes the interveners propose [11].There is an intricate operational environment whenever the UN undertakes interventions in intra-state conflicts where the government still has some control within that state or there is a legitimate elected government but its internal sovereignty is being challenged by other non-state actors within. This is common in many interventions in Africa such as Sierra Leone, South Sudan, Sudan, DRC and CAR. All these interventions in one way or another have operated in an environment where there is a legally recognized government and, in such cases, it has not been easy to freely execute its mandated tasks. The UN at this point assumes 
that it has the mandate to undertake all tasks including the UoF however at operational level; troops are always constrained by the government.

\section{RESEARCH METHODOLOGY}

This is a library-based research that has purely relied on secondary data. Data has been obtained from books, e-books, journals, UN publications and, on-line publications among others. The data so collected has been analysed thematically so as "to establish the key themes and trends from which findings, conclusions, and recommendations have been drawn."

\section{FINDINGS AND DISCUSSIONS}

\subsection{Challenges Facing Mandate Implementation in UN Missions}

Undoubtedly, UN mandates are executed in complex environments, and in some instances, peacekeeping troops and UN civilian personnel are caught in the crossfire. The 1994, UNSG report noted that PKOs operate in an environment with a multiplicity of armed factions and terrorist organizations, which at times leads to direct and indirect attacks on UN personnel, often resulting to loss of life and equipment [2]. Similarly, the 2015 High Implementation Panel on Peacekeeping Operations (HIPPO) report noted that "PKO are deployed in complex conflict settings, often in insecure environments, all too often lack capabilities required to implement their mandates, and, in some cases, operate in the absence of an underpinning peace process. In such conditions, peace operations struggle to achieve their objectives" [12].

In some instances, PKOs are faced with challenges emanating from multi-State troops compositions leading to challenges related to "mix of capabilities, procedure, equipment, language, customs, and ideology existing within the mission groups" [1]. This necessitates extensive prior and in-theatre training and orientation of troops before starting the actual operations. This further strain the UNs ability to execute its mandates given that already it is burdened by the inability to deploy sufficient and properly equipped troops due to budget constraints. The HIPPO report noted that, "mandates and missions are produced on the basis of templates instead of tailored to support situation-specific political strategies, and technical and military approaches come at the expense of strengthened political efforts" [12]. Field Mission planning has always commenced and conducted at the UNHQs without proper appreciation of the existing local field dynamics and these operations especially military operations are driven by the logistics plan rather that the logistics plan being driven by the military operations plan.

Prior to the 2015 HIPPO report [12], the UN has made previous attempts to reform its operations in as far as International peace and security is concerned with emphasis on PSOs. The UN's first attempt was in 1992 through a report by the then UNSG Boutros Boutros-Ghali, “Agenda for Peace." Subsequent reports included; "The 1999 report of the Independent Inquiry into the Actions of the UN during the 1994 Genocide in Rwanda (Carlsson Report)," which was mainly concerned with the peacekeeping principles and their efficacy in the PoC; The 2000 report by "the Panel on UN Peace Operations" (Brahimi Report), which addressed the reports on killings in Srebrenica and Rwanda and was concerned with situations "where one party to a peace agreement clearly and incontrovertibly is violating its terms, continued equal treatment of all parties by the UN can in the best case result in ineffectiveness and, in the worst case, may amount to complicity with evil." The report was also concerned of the inability of the UN to respond to challenges to its mandate, and therefore recommended that "there was need for the organization to be given the means to do so in the future." It also recommended that the rules of engagement should be robust to such an extent that they would not force "UN contingents to cede the initiative to their attackers" [13]. In July 2009, the UN also issued a consultation document; "A New Partnership Agenda: Charting a New Horizon for UN Peacekeeping”, which generated a debate among member states on the contemporary peacekeeping challenges especially the PoC [13].

\subsection{Challenges Facing UN Intervention in CAR}

\subsubsection{Peace Agreement}

Respect to the letter and spirit of peace agreements play a critical role in the mandate implementation of the intervening third party. Effective conflict management and peace agreements depend on the proper analysis of the conflict with a critical examination of the actors, interests, positions and conflict mapping. Though conflict in CAR can be traced from the 1950s, characterized by "autocracy, a culture that tolerates vengeance, lack of effective governance structures as well as widespread sense of impunity," the wave of armed conflict that started in 2012 that led to the UN intervention in 2014, was seen as "opportunistic instead of being endemic or deeply entrenched" [14]. The conflict was superficially perceived as a religious conflict, between the largely Muslim Séléka and Christian Anti-Balaka, with limited involvement of state forces. However, its dynamics are engrained in the weak and inept political state infrastructure [15]. The subsequent peace agreement in 15 May 2015, therefore did not consider any other actors outside these three actors that signed the Peace Pact. This agreement has never been respected since the parties to the conflict were primarily driven by economic motivations while the government has delayed critical issues such as Disarmament Demobilisation Reintegration Repatriation (DDRR) and intercommunal reconciliation [16]. 
Lack of respect to the agreement and the disintegration of armed groups into multiple factions pursuing conflicting interests [16] marked the beginning of MINUSCA challenges in the implementation of its mandate. It therefore became difficult to hold to account those that renege from the agreement since it is not clear which faction was involved in the signing of the agreement. Arising from this, the peace agreement aimed to address these conflict dynamics oblivious of the existence of other local conflict dynamics which involve farmers and pastoralists [16]. These are conflicts that mainly targeted civilians which led to the perception that the MINUSCA is unable to end the violence. Historically, conflict resolution in CAR has been between political elites and rebel leaders. They are however unlikely to hold since they are negotiated in an atmosphere of replete with high levels of distrust with both parties seeking access to power and resources [17].

\subsubsection{Poor Government Institutional Capabilities}

Central African Republic's national security forces place a lot of burden on the MINUSCA PKO due to the fact that the police and gendarmerie do not have capacity to secure the areas that have been stabilized by MINUSCA. The authorized MINUSCA's "troop ceiling is 11,650 military personnel, including 480 military observers and military staff officers, 2,080 police personnel and 108 corrections officers" [18]. This has allowed armed groups to reoccupy such areas, bringing the gains achieved to nothing. Arising from this, in 2017 the UNSG noted that there is a resurgence of violence within CAR which had overstretched the missions resources [19] and it is due to the state of affairs that the UNSCR 2387(2017), authorised an additional 900 troops [18]. The state security forces have limited involvement in the conflict since they are poorly resourced and overwhelmed [15].

There was also the challenge of lack of coordination of negotiation processes between various armed groups, African Union efforts, and those undertaken under the auspices of MINUSCA. This has created a complex environment with various quasi-finalized ceasefire agreements and competing dialogues leaving MINUSCA to work in a vacuum due poor national capability [20].

In addition to the task of "Protection of Civilians (PoC) and support to the peace process," MINUSCA, is also mandated to "support the rule of law and to ensure a secure environment for the delivery of humanitarian aid to support for the extension of state authority and for the Central African Armed Forces (FACA)" [18]. For effective execution of this mandate, MINUSCA was expected to coordinate its activities with the Government and the security forces in CAR. However, in CAR, the capability, morale and motivation of the national police force and civil servants is poor due to prolonged periods without salaries. As a result, the UN, the World Bank and the EU, combined efforts to pay these salaries despite the fact that there were no auditable payrolls. In this regard, it can be concluded that the MINUSCA started operations in a country with demotivated civil servants and police forces thus making it hard to ensure cooperation with some government agencies, which though mitigated by payment of salaries, could have had serious negative repercussions [21]. In 2017, Parfait Onanga-Anyanga, UN SRSG and Head of MINUSCA, said that, "harsh criticism of the Mission within the country reflected frustration over the Government's lack of capacity as well as largely self-inflicted persistent insecurity characterized by each side expecting MINUSCA to fight their perceived enemies" [24].

\subsubsection{Lack of Authority to Eliminate Armed Groups}

Another major challenge facing MINUSCA is lack of authorization in its mandate to use force purposely targeting the elimination or neutralising of armed groups. Some MINUSCA operations related to its mandated task of PoC where they have used pre-emptive force against such armed groups can be viewed as going beyond their mandate thereby compromising the required impartial existence. While supporting the 'government security forces in ensuring the establishment of a conducive environment for the political process, the PKO has been perceived as being biased and an extension of the National armed forces (FACA). This means that its role in supporting political processes at the national and subnational levels is compromised.

\subsubsection{Conflicting Mandates}

The current UN intervention in CAR was preceded by an African Union led mission (MISCA) at the same time both the AU mission and the current UN mission have had to endure the complex working relationship with the French mission (Sangaris) which is pursuing its own interests. The mandates of MINUSCA and that of the French Sangaris and their leaderships do not serve the same purpose. The French intervention in CAR further complicated subsequent mandate implementation. French deployed an intervention force in CAR in 2013 under "an operation codenamed "operation Sangaris." This was done under the terms of a quadripartite defence agreement signed between France and the newly independent countries of Chad, CAR, and the Republic of the Congo in 1960" [17].

Prior to complete rehatting from the AU to the UN, there was a challenge for the UN and AU in managing "the complicated and often competitive relations with sub-regional organizations" [21]. Although this situation was dealt with through an AU-UN handover, the process was not very smooth. This was due to the challenges related to absorbing African contingents and getting them ready. There were major challenges related to equipment, training and the way these contingents functioned. Indeed, it was a tall order for the UN to bridge the capacity gap through re-hatting. Some of the African contingents were omitted, especially those from Equatorial Guinea and the DRC due to specific concerns about them. Some of the troops from "the Mission 
Consolidation of Peace in Central Africa (MICOPAX)" under "the Economic Community of Central African States (ECCAs)," which MINUSCA absorbed, were underequipped undertrained, and some, especially those from the DRC, were not regularly paid. Imposing order and security on them was thus challenging for MINUSCA, a challenge that had also faced the AU before it [21]. This initially being a sub-regional peace initiative, most of the troops were sourced from the neighbouring countries some of whom having little or no peacekeeping experience.

Table 4.1 List of Peacekeeping and Peacebuilding Missions in the Central African Republic

\begin{tabular}{|c|c|c|c|}
\hline Acronym & Official Name & Date Authorised & Mandating Organization \\
\hline MISAB & $\begin{array}{l}\text { "Inter-African Mission to Monitor the } \\
\text { Implementation of the Bangui Agreements } \\
\text { (Mission Intera-fricaine de surveillance des } \\
\text { accords de Bangui)" }\end{array}$ & January 1997 & $\mathrm{OAU}$ \\
\hline MINURCA & $\begin{array}{l}\text { "Mission in the Central African UN Republic } \\
\text { (Mission des Nations Unies en République } \\
\text { Centrafricaine)" }\end{array}$ & April 1998 & UN \\
\hline \multirow[t]{2}{*}{ BONUCA } & $\begin{array}{l}\text { "Peacebuilding Support Office in UN the } \\
\text { Central African Republic (Bureau des Nations } \\
\text { Unies pour la consolidation de la paix en } \\
\text { République Centrafricaine)" }\end{array}$ & December 1999 & UN \\
\hline & $\begin{array}{l}\text { "CEN-SAD Peacekeeping and Security Force } \\
\text { in the Central African Republic (CEN- (Force } \\
\text { de maintien de la paix et de la SAD)" }\end{array}$ & December 2001 & $\begin{array}{l}\text { Community of Sahel- Saharan } \\
\text { States (subsequently sécurité } \\
\text { de la CEN-SAD en endorsed } \\
\text { by the AU) Centrafrique) }\end{array}$ \\
\hline FOMUC & $\begin{array}{l}\text { "Multinational Force in the Central (Force } \\
\text { multinationale en Centrafrique) African States } \\
\text { (CEMAC)" }\end{array}$ & October 2002 & $\begin{array}{l}\text { Economic and Monetary } \\
\text { African Republic Community } \\
\text { of Central }\end{array}$ \\
\hline EUFOR & $\begin{array}{l}\text { "EU Force in Chad and the Central } \\
\text { Chad/CAR African Republic (Mission de } \\
\text { l'Union européenne au Tchad et en } \\
\text { République Centrafricaine)" }\end{array}$ & October 2007 & UN \\
\hline MICOPAX & $\begin{array}{l}\text { "Peace Consolidation Mission in the Central } \\
\text { African Republic (Mission de consolidation } \\
\text { de la paix en Centrafrique) (ECCAS)" }\end{array}$ & June 2008 & $\begin{array}{l}\text { Economic Community of } \\
\text { Central African States }\end{array}$ \\
\hline BINUCA & $\begin{array}{l}\text { "UN Integrated Peacebuilding Office in the } \\
\text { Central African Republic (Bureau Intégré de } \\
\text { l'Organisation des Nations Unies en } \\
\text { Centrafrique)" }\end{array}$ & April 2009 & UN \\
\hline ICR-LRA & $\begin{array}{l}\text { "Regional Cooperation Initiative for the } \\
\text { Elimination of the Lord's Resistance Army } \\
\text { (Initiative de coopération régionale contre } \\
\text { l'Armée de résistance du Seigneur)" }\end{array}$ & November 2011 & $\mathrm{AU}$ \\
\hline MISCA & $\begin{array}{l}\text { "African-led International Support Mission to } \\
\text { the Central African Republic (Mission } \\
\text { internationale de soutien à la Centrafrique } \\
\text { sous conduite Africaine)" }\end{array}$ & December 2013 & $\mathrm{AU}$ \\
\hline MINUSCA & $\begin{array}{l}\text { "UN Multidimensional Integrated } \\
\text { Stabilization Mission in the Central African } \\
\text { Republic (Mission multidimensionnelle } \\
\text { intégrée des Nations Unies pour la } \\
\text { stabilisation en République Centrafricaine)" }\end{array}$ & April 2014 & UN \\
\hline
\end{tabular}

Source: Zahar, Marie-Joëlle, and Delphine Mechoulan [17].

\subsubsection{Resource Constraints}

The UN points out that its mandate is also faced by the challenge of failed Security Sector Reforms (SSRs). Sometimes, these reforms do not fail due to political challenges but due to lack of financial commitment to ensure sufficient funding for such 
SSR efforts [12]. In the case of CAR, MINUSCA is left with lack of enough funding to effectively carry out its mandate at the same time the government has delayed critical issues such as DDRR is concerned [16]. It thus means that some operations have to be downscaled to reflect this reality. This challenge was also cited by Stian Kjeksrud and Lotte Vermeij who point out that one of the challenges facing MINUSCA forces was, "lack of realistic missions that are not matched with realistic means and resources or backed by real political will for long-term peace" [22].

Other challenge include lack of mobility due to insufficient of air assets, and particularly helicopters with night flying capability further compounded by the logistic challenges arising from poor road infrastructure to support the troops [16]. According to the UN principles and guidelines for PKOs, "the deployment of troops and police must be accompanied by efforts to restore the State's monopoly over the legitimate UoF; re-establish the rule of law and strengthen respect for human rights; foster the emergence of legitimate and effective institutions of governance; and promote socio economic recovery" [23].

\subsubsection{Credibility of Peacekeepers}

Allegations of SEA committed by some of these troops led to the undermining the credibility of the UN [24]. In early 2016, fresh cases of SEA in Bambari were reported allegedly committed by MINUSCA peacekeepers from the Republic of Congo (RoC) and the Democratic Republic of Congo (DRC). Although these peacekeepers were eventually repatriated, the credibility of the MINUSCA had been dealt a major blow. The failure by UN and AU to vet the troops from inherited from MISCA and MICOPAX was blamed for these incidents of SEA. This is due to the fact although the AU had not formally recruited them into MISCA, the troops from DRC had self-deployed due to their proximity and being within the same conflict system with CAR. Subsequently, these were eventually absorbed into MINUSCA when MISCA was handed over to the UN mission. Although UNDPKO had complained earlier on concerns about the capacity of these troops and the human records of some of their commanders [21] it had no choice but accept them due to the fact that no other TCC was ready to send troops to CAR.

This was made manifest when a report by the HRW News showed at least 18 civilians, including women and children, had been killed by Soldiers from the ROC, while serving as peacekeepers in CAR between December 2013 and June 2015 . These were often through summary executions near a peacekeeping base in Boali, CAR. These crimes took place while the peacekeepers served under the MISCA and MINUSCA [25]. It is important to note that third party intervention in CAR has taken place since 1997. (See table 1 above)

\section{CONCLUSION AND RECOMMENDATIONS}

\subsection{Conclusions}

Based on the study findings, it can be concluded that the execution of the UN Mandate in Central African Republic is implemented in complex environments. The UN during its planning for PKOs may have not considered the status of national institutional capabilities in CAR that were expected to support MINUSCA. It can also be concluded that that challenges to the MNUSCA mandate execution lies on the ability and capability of the rehatted troops from MISCA to MINUSCA which emanated from the inherent inability of the UN to raise troops for its PKOs. The conflict arising from troops deployed operating outside the United Nation mandates, such as the Sangaris often lead to duplication of effort and at times operate at cross purpose with UN mandated troops. At times UN troops get blamed for acts they never committed due to the deployment of such troops.

\subsection{Recommendations}

Review of the principles of peacekeeping; impartiality, consent and non-UoF except in self-defence as well as defence of the mandate must be reviewed so as to be effective in the contemporary PKOs.

\section{REFERENCES}

[1] Trevor, Findlay (ed), SIPRI Research Report No. 12, Challenges for the New Peacekeepers, (New York: Oxford University Press, 1996).

[2] United Nations, 'Report of the Secretary General on the Work of the Organization', UN Document A/49/1, September 1994.

[3] UN News Ban 'regrets Austria's decision to withdraw troops from UN mission in Golan Heights,' 6 June 2013. https://news.un.org/en/story/2013/06/441582

[4] United Nations, 'United Nations Peacekeeping: The Challenges Ahead,' (Paper Presented during the Parliamentary hearing from 20 to 21 November, 2008, United Nations, New York) pp. 2-3.

[5] Murphy Ray, UN Peacekeeping in Lebanon, Somalia and Kosovo: Operational and Legal Issues.

[6] Terry, Mays M., Africa's First Peacekeeping Operation: The OAU in Chad, 1991-1982, (Westport: Greenwood Press, 2002).

[7] Bere, Mathieu "Armed Rebellion, Violent Extremism, and the Challenges of International Intervention in Mali." African Conflict and Peacebuilding Review 7, no. 2 (2017). http://www.jstor.org/stable/10.2979/africonfpeacrevi.7.2.03. p66 
[8] United Nations Department of Peace Operations Department of Operational Support, Guidelines on peacekeeping Capability readiness System

(PCRS) January

2019. http://dag.un.org/bitstream/handle/11176/400901/2019.01\%20Peacekeeping\%20Capability\%20Readiness\%20System_Guidelines. pdf? sequence $=1 \&$ is Allowed $=y$

[9] Lewis, Mudge. In the Central African Republic, AU Peacekeepers Carried Out an Egregious Crime". Human Rights Watch. https://www.hrw.org/news/2018/08/10/central-african-republic-au-peacekeepers-carried-out-egregious-crime. 4 February 2020.

[10] Dorussen, Han, and Theodora-Ismene Gizelis. "Into the Lion's Den: Local Responses to UN Peacekeeping." Journal of Peace Research 50, no. 6 (2013): 691-706. http://www.jstor.org/stable/24557163.

[11] Nalbandov, Robert, Foreign Intervention in Ethnic Conflicts, (Burlington: Ashgate, 2009).

[12] United Nations (2015) Report of the High-level Independent Panel on Peace Operations (HIPPO) on uniting our strengths for peace: Politics, partnership and people. UN Document No. A/70/95S/2015/446.

[13] Louise Fréchette, UN Peacekeeping: 20 Years of Reform, CIGI Papers no. 2 , April 2012. https://www.cigionline.org/sites/default/files/un_peacekeeping_1.pdf. Accessed on 3 March 2020.

[14] Lise Horward, Assessing the Effectiveness of the UN Mission in the Central African Republic, IPI Global Observatory, 21 November 2019. https://theglobalobservatory.org/2019/11/assessing-effectiveness-un-mission-central-african-republic/.

[15] Raleigh, Clionadh, and Caitriona Dowd. Report. Edited by Duffy Grace. Armed Conflict Location \& Event Data Project, 2015. Accessed March 10, 2020. www.jstor.org/stable/resrep03794.

[16] Stimson Center. Report. Stimson Center, 2016. Accessed March 10, 2020. www.jstor.org/stable/resrep10812.

[17] Zahar, Marie-Joëlle, and Delphine Mechoulan. Peace by Pieces?: Local Mediation and Sustainable Peace in the Central African Republic. Report. International Peace Institute, 2017. 5-12. Accessed March $10,2020$. www.jstor.org/stable/resrep17504.6.

[18] UNSCR 2387 (2017), UNSC Unanimously Adopting Resolution Security Council Extends Mandate, Increases Troop Levels of Stabilization Mission in Central African Republic (SC/1306815 November 2017) https://www.un.org/press/en/2017/sc13068.doc.htm. Accessed on 6 January 2020

[19] United Nations, UNSG Reports/2017/865, 18 October 2017

[20] International Peace Institute (October 2018.) Prioritizing and Sequencing Peacekeeping Mandates: The Case of MINUSCA. IPI. https://www.ipinst.org/wp-content/uploads/2018/10/1810_The-Case-of-MINUSCA-English.pdf. Accessed on 20 December 2019.

[21] Carayannis, Tatiana and Fowlis, Mignonne. Lessons from African Union-United Nations cooperation in peace operations in the Central African Republic. African Security Review. Vol.26. (2017): 220-236. 10.1080/10246029.2017.1302707.

[22] Stian Kjeksrud and Lotte Vermeij, "Protecting governments from insurgencies: The Democratic Republic of the Congo and Mali," UN Peacekeeping Doctrine in a New Era: Adapting to Stabilization, Protection and New Threats" eds. Chiyuki Aoi, Cedric de Coning and John Karlsrud (New York, Routledge, 2017).

[23] UN 'Department of Peacekeeping Operations and Department of Field Support, United Nations Peacekeeping Operations: Principles and Guidelines’ (New York: UN, 2008), pp. 87-88.

[24] UN, Central African Republic: meeting reported victim of sexual assault, UNICEF provides 'every possible help' (2015). Accessed on September 6, 2019 https://www.un.org/africarenewal/news/central-african-republic-meeting-reported-victim-sexualassault-unicef-provides-every-possible

[25] Human Rights Watch News. (June 7, 2016). 'Central African Republic: Murder by Peacekeepers Discovery of Mass Grave Provides New Evidence.’ Accessed on December 7, 2019. https://www.hrw.org/news/2016/06/07/central-african-republic-murderpeacekeepers

\section{About the Author}

${ }^{1}$ Elijah Mwasi Mwanyika is a Kenya Defence Forces senior officer with a career spanning over 30 years. He is a graduate of the National Defence College Kenya, a PhD Candidate in Peace and Conflict Studies at Masinde Muliro University of Science and Technology in Kenya, a holder of MA in Defence Studies from Kings College London, MA in Sustainable Peace from the University for Peace Costa Rica and a Post Graduate Diploma in Strategic Management from the Chartered Management Institute - UK. Mwanyika has served as a peacekeeper, staff officer and military observer in the following UN missions; UNPROFOR (Former Yugoslavia), UNAMSIL (Sierra Leone) and UNMISS (South Sudan). He also served as a seconded officer at the UN HQs in the Department of Peace Operations. 